\title{
Biomechanical analysis of combined treatment of high calcium and bisphosphonate in tibia of steroid-treated growing-phase rats
}

\author{
Yusuke YOKOTE${ }^{1}$, Emi KIMURA², Mitsutaka KIMURA² and Yoshio KOZONO³ \\ ${ }^{1}$ Yokote Dental Clinic, 107-1 Koro, Koderacho, Himeji, Hyogo, 679-2151, Japan \\ ${ }^{2}$ Division of Developmental Stomatognathic Function Science, Kyushu Dental College, 2-6-1 Manazuru, Kokurakita-ku, Kitakyushu 803-8580, \\ Japan \\ ${ }^{3}$ Division of Biomaterials, Kyushu Dental College, 2-6-1 Manazuru, Kokurakita-ku, Kitakyushu 803-8580, Japan \\ Corresponding author, Emi Kimura; E-mail: emi0820@tree.odn.ne.jp
}

Childhood systemic diseases are commonly treated with steroids. Consequently, steroid-induced osteoporosis is often observed as a side effect of steroid therapy. However, osteoporosis of tibia resulting from steroid therapy has not been reported yet. Herein we constructed a steroid-induced osteoporosis in tibia of the growing phase rats to examine internal structural changes of the bone and tried to find out the effect of bisphosphonates as a new and early treatment method. Biomechanical analysis was performed using two-dimensional microdensitometry and three-dimensional pQCT method. In addition, the following evaluations were carried out: noninvasive bone strength measurements in steroid-induced osteoporotic rat tibiae; comparing the effectiveness of single high-calcium diet versus combined treatment of high calcium and bisphosphonate for osteoporosis; and quantitative measurement of four elements (Ca, $\mathrm{P}, \mathrm{Mg}$, $\mathrm{Zn})$ in bone matrix. Our data suggested that a combined treatment of high calcium and bisphosphonate was an effective new method to improve and treat steroid-induced osteoporosis in childhood.

Key words: Bisphosphonate, pQCT, Rat

Received Feb 1, 2008: Accepted Mar 17, 2008

\section{INTRODUCTION}

Steroids are used to treat various diseases, including systemic lupus erythematosus (SLE) $)^{1}$, juvenile rheumatoid arthritis ${ }^{2}$, nephrotic syndrome ${ }^{3,4)}$, serious bronchial asthma ${ }^{5)}$, idiopathic thrombocytopenic purpura $^{6)}$, brain tumors ${ }^{7}$, and lymphangioma ${ }^{8}$ during childhood. However, steroid-induced osteoporosis (secondary osteoporosis) is one of the most common childhood metabolic bone diseases in childhood owing to the side effect of long-term steroid treatment.

Childhood is an important stage of development in which bone mass gradually increases through bone resorption and formation to reach the peak bone mass. Therefore, the application of steroids during this period inhibits bone growth and may leave permanent damage ${ }^{3,9}$. During childhood, the bone is in a state of high turnover and bone density progressively increases, showing maximal increment during puberty. Since enhancement of the absolute value of peak bone mass is considered crucial for prevention of fractures and osteoporosis in late adulthood, maintenance of normal bone metabolism during childhood to reach as much as higher peak bone mass is an essential target.

Recent studies showed the effectiveness of bisphosphonate treatment in steroid-induced osteoporosis $^{10-14)}$. However, there is no report on the effectiveness of bisphosphonate treatment for osteoporosis of tibial diaphysis at the growing stage. In the present study, we sought to assess the effectiveness of bisphosphonate treatment combined with high calcium supply in steroid-induced osteoporosis, especially considering the active metabolic turnover of bone during childhood. To this end, the effects of the proposed treatment were biomechanically analyzed in the tibial diaphyses of growing-phase rats after introducing a steroid-induced osteoporosis (secondary osteoporosis) condition. In addition, the quantitative analysis of four elements $-\mathrm{Ca}, \mathrm{P}, \mathrm{Mg}$, $\mathrm{Zn}$ - was also performed. These trace elements are essential to bone growth and turnover during the growing phase.

\section{MATERIALS AND METHODS}

Rat diet was prepared in our laboratory according to a previous method described by Gunjima et $a l .{ }^{15)}$. Rats were fed a standard diet (Oriental Combination A diet, Oriental Yeast Co. Ltd., Tokyo, Japan) as well as a high-calcium diet which consisted of $74 \%$ Oriental Conbination A diet and 26\% UNICAL calcium (UNICAL ${ }^{\circledR}$, Unical Calcium Food Co. Ltd., Tokyo, Japan). Table 1 shows the compositions of the experimental diets.

On the steroid used in the present study, it was prednisolone sodium succinate (water-soluble Prednine ${ }^{\circledR}$, Shionogi Co. Ltd., Osaka, Japan), i.e., 
monosodium $11 \beta, 17,21$-trihydroxypregna-1,4-diene3,20-dione 21-succinate. As for the bisphosphonate, it was etidronate disodium $\left(\right.$ Didronel $^{\circledR}$, Sumitomo Pharmaceuticals, Osaka, Japan), i.e., disodium dihydrogen (1-hydroxyethylidene) bisphosphonate.

\section{Experimental animals}

Eight-week-old male Wistar rats $(n=50)$ weighing approximately $258 \mathrm{~g}$ (Seac Yoshitomi Co. Ltd., Fukuoka, Japan) were randomly divided into five groups of 10 rats each. The animals were housed in individual cages and maintained at $22 \pm 1^{\circ} \mathrm{C}$ in a 12 hour light-dark cycle. Food and water were supplied ad libitum.

As shown in Table 2, the rats were classified into five groups. In the 6-week control group (code: 6Co), rats were fed a standard diet with tap water for six weeks. In the 6 -week steroid group (code: $6 \mathrm{St}$ ), rats were fed a standard diet with tap water and were administered water-soluble Prednine ${ }^{\circledR}(30 \mathrm{mg} / \mathrm{kg} / 2$ days) orally for six weeks.

In the 9-week control group (code: 9Co), rats were fed a standard diet with tap water for nine weeks. In the 9-week steroid and high-calcium diet group (code: $6 \mathrm{St} \cdot 3 \mathrm{Hc}$ ), rats were fed a standard diet with tap water and given water-soluble Prednine ${ }^{\circledR}$ (30 mg/ kg/2 days) orally for six weeks, followed by a high-calcium diet with tap water for three weeks. In the 9-week steroid, high calcium, and bisphosphonate group (code: $6 \mathrm{St} \cdot 3 \mathrm{HcBp}$ ), rats were fed a standard diet with tap water and were administered watersoluble Prednine ${ }^{\circledR}$ (30 mg/kg/2 days) orally for six weeks, followed by high-calcium diet with tap water and subcutaneous injection of bisphosphonate $(5 \mathrm{mg} /$ $\mathrm{kg}$ /day) into the dorsal skin for three weeks.

At the end of six weeks (groups 6Co and 6St) or nine weeks (groups 9Co, $6 \mathrm{St} \cdot 3 \mathrm{Hc}$, and $6 \mathrm{St} \cdot 3 \mathrm{HcBp}$ ), the animals were sacrificed under deep anesthesia by intra-abdominal injection of thiamylal sodium (Isozol $^{\circledR}$, Mitsubishi Pharmaceutical Co. Ltd., Osaka, Japan) combined with diethyl ether. The tibiae were removed and fixed in 10\% neutral formalin solution. All the experimental procedures were conducted with due consideration for ethical care and handling of experimental animals, based on the Rules for Animal Experimentation of Kyushu Dental College.

Table 1 Compositions of experimental diets (\%)

\begin{tabular}{|c|c|c|}
\hline Ingredients & Standard diet & High-calcium diet \\
\hline$\beta$-Corn starch & 38.00 & 28.12 \\
\hline Vitamin-free casein & 25.00 & 18.50 \\
\hline$\alpha$-Potato starch & 10.00 & 7.40 \\
\hline Cellulose powder & 8.00 & 5.92 \\
\hline Soy bean oil & 6.00 & 4.44 \\
\hline Mineral mixture ${ }^{1)}$ & 6.00 & 4.44 \\
\hline Granulated sugar & 5.00 & 3.70 \\
\hline Vitamin mixture & 2.00 & 1.48 \\
\hline \multirow[t]{2}{*}{$\mathrm{UNICAL}^{2)}$} & -- & 26.00 \\
\hline & 100.00 & 100.00 \\
\hline $\begin{array}{l}\text { Published compositions: } \\
{ }^{1)}(\mathrm{g} / 100 \mathrm{~g}): \mathrm{NaCl}, 4.66 ; \mathrm{KI}, 0.0 \\
4-5 \mathrm{H}_{2} \mathrm{O}, 0.12 ; \mathrm{CuSO}_{4} \cdot 5 \mathrm{H}_{2} \mathrm{O} \\
{ }^{2)}(\mathrm{mg} / 100 \mathrm{~g})\end{array}$ & $\begin{array}{l}\mathrm{O}_{4}, 9.35 ; \mathrm{MgSO} \\
\text { tate, } 35.09\end{array}$ & $56 ;$ Fe-citrate, $3.18 ; \mathrm{MnSO}_{4} \cdot$ \\
\hline
\end{tabular}

Table 2 Classifications of rats by diet and treatment

\begin{tabular}{lll}
\hline & \multicolumn{1}{c}{ Code } & \multicolumn{1}{c}{ Diet and treatment } \\
\hline \multirow{2}{*}{ 6-week group } & $6 \mathrm{Co}$ & Standard diet with tap water for 6 weeks (control) \\
& $6 \mathrm{St}$ & Standard diet with tap water and steroid for 6 weeks \\
\hline & $9 \mathrm{Co}$ & Standard diet with tap water for 9 weeks (control) \\
& $6 \mathrm{St} \cdot 3 \mathrm{Hc}$ & $\begin{array}{l}\text { Standard diet with tap water and steroid for } 6 \text { weeks followed by high-calcium diet } \\
\text { with tap water for } 3 \text { weeks }\end{array}$ \\
& $6 \mathrm{St} \cdot 3 \mathrm{HcBp}$ & $\begin{array}{l}\text { Standard diet with tap water and steroid for } 6 \text { weeks followed by high-calcium diet } \\
\text { with tap water and bisphonate for } 3 \text { weeks }\end{array}$ \\
\hline
\end{tabular}




\section{Microdensitometry (MD)}

After fixation in 10\% neutral formalin solution, the tibiae were exposed 60 seconds to X-ray under the conditions of $35 \mathrm{kVp}$ tube voltage and $5 \mathrm{~mA}$ tube current. Soft X-ray photographs were taken with a focus-film distance of $70 \mathrm{~cm}$ (EMS-2, Softex Co. Ltd., Tokyo, Japan). Under these circumstances, with a view to evaluating the bone density objectively on the soft X-ray film, an aluminum step wedge $(25 \mathrm{~mm}$ in length, $0.01-1.0 \mathrm{~mm}$ in thickness) was bonded to the soft X-ray film (Fuji Softex Film FG) before exposure. Optical observation (MD method) was performed using a densitometer (PDS-15, Konica Co. Ltd., Tokyo, Japan). Measurement of the bone density was done by scanning the center of the tibial diaphyses with a light beam of $10 \times 500 \mu \mathrm{m}$ slit width at a speed of $0.1 \mathrm{~mm} / \mathrm{sec}$. Optical density of the bone was converted to the thickness of aluminum by the density pattern of the standard aluminum wedge, and expressed as aluminum equivalent (mmAl).

\section{Peripheral quantitative computed tomography (pQCT)}

The tibial diaphyses were scanned at a distance of $15.5 \mathrm{~mm}$ from the proximal growth plate by pQCT (XCT Research SA+, Stratec Medizintechnik GmbH, Pforzheim, Germany) with $0.12 \times 0.12 \mathrm{~mm}$ pixel and $0.46 \mathrm{~mm}$ slice thickness (Fig. 1). Cortical bone mineral density $\left(\mathrm{CtBMD}, \mathrm{mg} / \mathrm{cm}^{3}\right)$, cortical bone mineral content (CtBMC, $\mathrm{mg} / \mathrm{mm}$ ), and cortical bone cross-sectional area (CtCSA, $\mathrm{mm}^{2}$ ) were analyzed using pQCT software, Rev. 6.00. Cortical bone area was defined as the section that corresponded to a pixel area over a threshold of $690 \mathrm{mg} / \mathrm{cm}^{3}$. Cortical bone thickness (CtThc, mm), as well as the circumferences of cortical bone periosteum (Peri, $\mathrm{mm}$ ) and endosteum (Endo, $\mathrm{mm}$ ), were calculated from the cross-sectional total bone area and cross-sectional cortical bone area.

Stress-strain index (SSI) was also analyzed by pQCT as a noninvasive index of whole bone strength using a threshold value of $464 \mathrm{mg} / \mathrm{cm}^{3}$. SSI was calculated using the following equation:

$$
\mathrm{SSI}=\mathrm{CtBD} \times \mathrm{Z} / \mathrm{NCtBD}
$$

where $\mathrm{CtBD}$ is cortical bone mineral density in $\mathrm{mg} /$ $\mathrm{cm}^{3} ; \mathrm{Z}$ is section modulus in $\mathrm{mm}^{3}$, and NCtBD is normal value of cortical bone density at $1,200 \mathrm{mg} /$ $\mathrm{cm}^{3}$ with reference to the $\mathrm{x}$ and polar axes (xSSI, pSSI). xSSI and pSSI were used as determinants of bending and torsional strengths respectively.

Quantitative measurements of calcium, phosphorus, magnesium, and zinc

Quantitative measurements of bone mineral contents

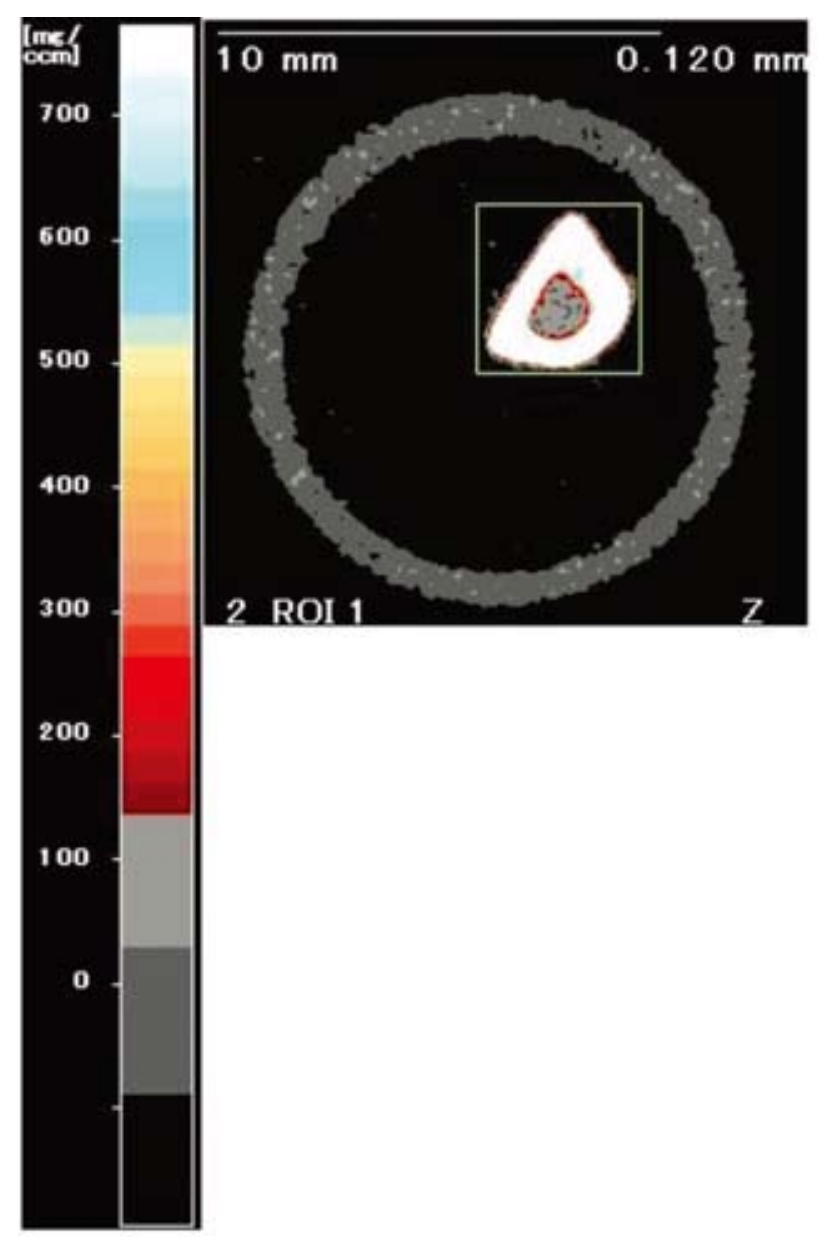

Fig. 1 A representative image of tibial diaphyseal bone scanned at a distance of $15.5 \mathrm{~mm}$ from the proximal growth plate.

were performed as described in our previous study by Yahara et $a l .{ }^{16)}$. Briefly, tibial diaphyses were washed in pure water after fixation in neutral buffer formalin. This was followed by rinsing in ethyl alcohol and drying at $60^{\circ} \mathrm{C}$ for one hour, and then weighed (0.06-0.12 mg). After this step, the samples were placed in a beaker (Pyrex heatresistant glass), where $5 \mathrm{ml}$ of hydrochloric acid and $3 \mathrm{ml}$ of nitric acid (both of analytical grade, Wako Pure Chemical Industries Co. Ltd., Osaka, Japan) were added. Content was heated in a sand bath on a hot plate for one hour to dissociate the content. Ultrapure water was added to the resulting solution to make a sample solution with a total volume of 50 $\mathrm{ml}$. This solution was diluted 10 times with ultrapure water for analysis, whereby $\mathrm{Ca}, \mathrm{P}, \mathrm{Mg}$, and $\mathrm{Zn}$ were quantitatively analyzed using an inductively coupled plasma atomic emission spectrometer (ICPS8100, Shimadzu Co. Ltd., Kyoto, Japan) and determined according to the standard calibration 
curves of these four minerals (Ca: 0, 8, $50 \mathrm{ppm}$; P: 0, 8, 40 ppm; Mg: 0, 0.4, 2 ppm; Zn: 0, 0.02, 0.1 ppm). Ratios of these four elements in the samples were expressed in percentage.

Statistical analysis

Statistical analyses were performed using t-test and one-way analysis of variance (ANOVA) for data with a significant difference in post hoc test. Data were expressed as mean \pm standard deviation (SD).

\section{RESULTS}

$M D$

No significant difference was detected between groups 6Co and 6St. A significant difference was observed between groups $6 \mathrm{St} \cdot 3 \mathrm{HcBp}$ and $6 \mathrm{St} \cdot 3 \mathrm{Hc}$ $(\mathrm{p}<0.01)($ Table 3).

$p Q C T$

pQCT analysis demonstrated that CtBMD and Peri were significantly lower in group 6St than in group 6 Co $(p<0.01$ and $p<0.05$, respectively). On the other hand, CtBMC and CtCSA were significantly higher in group 6St than in group $6 \mathrm{Co}(\mathrm{p}<0.05$ and $\mathrm{p}<0.05$, respectively). With the 9 -week groups $(9 \mathrm{Co}, 6 \mathrm{St} \cdot 3 \mathrm{Hc}$, and $6 \mathrm{St} \cdot 3 \mathrm{HcBp}$ ), all bone parameters were lower in group $6 \mathrm{St} \cdot 3 \mathrm{Hc}$ than in control group 9Co. CtBMD, CtBMC, CtCSA, and Peri were significantly lower in group $6 \mathrm{St} \cdot 3 \mathrm{Hc}$ than in group $9 \mathrm{Co}(\mathrm{p}<0.05, \mathrm{p}<0.05$, $\mathrm{p}<0.01$, and $\mathrm{p}<0.01$, respectively). On the other hand, most of the cortical bone parameters, CtBMD, CtBMC, CtCSA, Peri, and Endo were significantly higher in group $6 \mathrm{St} \cdot 3 \mathrm{HcBp}$ than in group $6 \mathrm{St} \cdot 3 \mathrm{Hc}$

Table 3 Densities of tibial diaphyses in rats based on equivalent thickness of aluminum

\begin{tabular}{cccccc}
\hline & \multicolumn{2}{c}{6 -week group } & \multicolumn{3}{c}{9 -week group } \\
\cline { 2 - 6 } & $6 \mathrm{Co}$ & $6 \mathrm{St}$ & $9 \mathrm{Co}$ & $6 \mathrm{St} \cdot 3 \mathrm{Hc}$ & $6 \mathrm{St} \cdot 3 \mathrm{HcBp}$ \\
\hline Density (mmAI) & $1.10 \pm 0.07$ & $1.16 \pm 0.08$ & $1.12 \pm 0.03$ & $1.13 \pm 0.04^{\mathrm{a}}$ & $1.23 \pm 0.09^{\mathrm{b}}$ \\
\hline
\end{tabular}

Data are shown as mean \pm SD. a: $\mathrm{p}<0.01$ vs. 9 Co $\quad$ b: $\mathrm{p}<0.01$ vs. $6 \mathrm{St} \cdot 3 \mathrm{Hc}$

Table $4 \quad$ pQCT measurement results of tibial diaphyses in rats

\begin{tabular}{|c|c|c|c|c|c|}
\hline & \multicolumn{2}{|c|}{ 6-week group } & \multicolumn{3}{|c|}{ 9-week group } \\
\hline & $6 \mathrm{Co}$ & $6 \mathrm{St}$ & $9 \mathrm{Co}$ & $6 \mathrm{St} \cdot 3 \mathrm{Hc}$ & $6 \mathrm{St} \cdot 3 \mathrm{HcBp}$ \\
\hline Cortical bone mineral density $\left(\mathrm{CtBMD}, 10^{3} \mathrm{mg} / \mathrm{cm}^{3}\right)$ & $1.28 \pm 0.01$ & $1.26 \pm 0.01^{x}$ & $1.28 \pm 0.02$ & $1.26 \pm 0.01^{\mathrm{b}}$ & $1.28 \pm 0.02^{\mathrm{d}}$ \\
\hline Cortical bone mineral content (CtBMC, $\mathrm{mg} / \mathrm{mm})$ & $5.54 \pm 0.36$ & $5.93 \pm 0.25^{\mathrm{y}}$ & $6.72 \pm 0.22$ & $5.46 \pm 0.91^{\mathrm{b}}$ & $6.46 \pm 0.50^{\mathrm{c}}$ \\
\hline Cortical bone cross-sectional area (CtCSA, $\mathrm{mm}^{2}$ ) & $4.32 \pm 0.30$ & $4.70 \pm 0.18^{\mathrm{y}}$ & $5.26 \pm 0.10$ & $4.30 \pm 0.63^{\mathrm{a}}$ & $5.20 \pm 0.43^{\mathrm{c}}$ \\
\hline Cortical Thickness (CtThc, mm) & $0.68 \pm 0.03$ & $0.65 \pm 0.03$ & $0.68 \pm 0.04$ & $0.60 \pm 0.07$ & $0.65 \pm 0.06$ \\
\hline Periosteum (Peri, mm) & $8.97 \pm 0.18$ & $8.66 \pm 0.24^{\mathrm{y}}$ & $9.86 \pm 0.25$ & $9.02 \pm 0.42^{\mathrm{a}}$ & $9.76 \pm 0.31^{\mathrm{c}}$ \\
\hline Endosteum (Endo, mm) & $3.97 \pm 1.17$ & $4.56 \pm 0.82$ & $5.57 \pm 0.48$ & $5.04 \pm 0.51$ & $5.68 \pm 0.13^{c}$ \\
\hline Stress Strain Index with reference to the $\mathrm{x}$-axis (xSSI) & $2.48 \pm 0.12$ & $2.17 \pm 0.26^{\mathrm{y}}$ & $3.28 \pm 0.17$ & $2.29 \pm 0.55^{\mathrm{a}}$ & $3.04 \pm 0.29^{\mathrm{c}}$ \\
\hline Stress Strain Index with reference to the polar-axis (pSSI) & $5.81 \pm 0.90$ & $4.33 \pm 0.50^{y}$ & $6.65 \pm 0.62$ & $4.95 \pm 0.43^{\mathrm{a}}$ & $4.90 \pm 0.44^{\mathrm{a}}$ \\
\hline
\end{tabular}

Data are shown as mean \pm SD. $\mathrm{x}: \mathrm{p}<0.01$, y: $\mathrm{p}<0.05$ vs. 6Co. a: $\mathrm{p}<0.01, \mathrm{~b}: \mathrm{p}<0.05$ vs. 9 Co. $\mathrm{c}: \mathrm{p}<0.01, \mathrm{~d}: \mathrm{p}<0.05$ vs. $6 \mathrm{St} \cdot 3 \mathrm{Hc}$

Table $5 \mathrm{Ca}, \mathrm{P}, \mathrm{Mg}$, and $\mathrm{Zn}$ mineral contents of tibial diaphyses in rats

\begin{tabular}{lrrrrc}
\hline & \multicolumn{2}{c}{6 -week group } & \multicolumn{3}{c}{9 -week group } \\
\cline { 2 - 6 } & \multicolumn{1}{c}{$6 \mathrm{Co}$} & $6 \mathrm{St}$ & $9 \mathrm{Co}$ & $6 \mathrm{St} \cdot 3 \mathrm{Hc}$ & $6 \mathrm{St} \cdot 3 \mathrm{HcBp}$ \\
$\mathrm{Ca}$ & $27.00 \pm 2.00$ & $25.00 \pm 1.00^{\mathrm{y}}$ & $26.00 \pm 1.00$ & $24.00 \pm 1.00^{\mathrm{a}}$ & $26.00 \pm 1.00^{\mathrm{b}}$ \\
$\mathrm{P}$ & $14.00 \pm 1.00$ & $13.00 \pm 2.00^{\mathrm{y}}$ & $12.00 \pm 1.00$ & $12.01 \pm 1.00$ & $13.00 \pm 1.00^{\mathrm{ac}}$ \\
$\mathrm{Mg}$ & $0.50 \pm 0.04$ & $0.45 \pm 0.05^{x}$ & $0.47 \pm 0.00$ & $0.42 \pm 0.04^{\mathrm{a}}$ & $0.47 \pm 0.03^{\mathrm{b}}$ \\
$\mathrm{Zn}$ & $0.04 \pm 0.00$ & $0.04 \pm 0.00^{x}$ & $0.05 \pm 0.00$ & $0.05 \pm 0.01$ & $0.10 \pm 0.04^{\mathrm{ab}}$ \\
\hline
\end{tabular}

Data are shown as mean \pm SD. $\mathrm{x}: \mathrm{p}<0.01$, y: $\mathrm{p}<0.05$ vs. 6 Co a: $\mathrm{p}<0.01$ vs. 9 Co b: $\mathrm{p}<0.01$, c: $\mathrm{p}<0.05$ vs. $6 \mathrm{St} \cdot 3 \mathrm{Hc}$ 
$(\mathrm{p}<0.05, \quad \mathrm{p}<0.05, \quad \mathrm{p}<0.01, \quad \mathrm{p}<0.01, \quad$ and $\mathrm{p}<0.01$, respectively) (Table 4$)$.

After six weeks, both xSSI and pSSI were markedly lower in group 6St than in group 6Co $(p<0.05$ and $p<0.05$, respectively). Similarly, after nine weeks, xSSI and pSSI were significantly lower in groups $6 \mathrm{St} \cdot 3 \mathrm{Hc}$ and $6 \mathrm{St} \cdot 3 \mathrm{HcBp}$ than in group $9 \mathrm{Co}$. On the other hand, xSSI of group $6 \mathrm{St} \cdot 3 \mathrm{HcBp}$ was significantly higher than that of group $6 \mathrm{St} \cdot 3 \mathrm{Hc}$ $(\mathrm{p}<0.01)$ (Table 4).

Quantitative measurements of $\mathrm{Ca}, \mathrm{P}, \mathrm{Mg}$ and $\mathrm{Zn}$

Amounts of $\mathrm{Ca}, \mathrm{P}, \mathrm{Mg}$, and $\mathrm{Zn}$ were significantly lower in group 6St than in group 6Co $(\mathrm{p}<0.05$, $\mathrm{p}<0.05, \mathrm{p}<0.01$, and $\mathrm{p}<0.01$, respectively). On the other hand, all the amounts of $\mathrm{Ca}, \mathrm{P}, \mathrm{Mg}$, and $\mathrm{Zn}$ were higher in group $6 \mathrm{St} \cdot 3 \mathrm{HcBp}$ than in group $6 \mathrm{St} \cdot 3 \mathrm{Hc} \quad(\mathrm{p}<0.01, \mathrm{p}<0.05, \quad \mathrm{p}<0.01, \quad$ and $\mathrm{p}<0.01$, respectively) (Table 5).

\section{DISCUSSION}

Osteoporosis is now considered as a patho-physiological condition of calcium deficit during aging depending on the acquired nutritional life. This condition is specifically characterized by a decrease in bone density without abnormalities of metabolic functions of the body. Therefore, prevention and treatment of osteoporosis are now well described. Recently, a new treatment method is proposed for osteoporosis due to calcium deficit during childhood $^{15-18)}$. On the other hand, it is now clear that the use of steroids for systemic diseases during childhood causes steroid-induced osteoporosis (secondary osteoporosis) as a side effect. However, prevention and treatment of this situation is not established yet.

Although osteoporosis due to steroids occurs early due to the high metabolic turnover in childhood, its quick detection and early treatment are also possible. By means of a steroid-induced secondary osteoporosis animal model in the present study, we clearly showed the efficiency of a combined treatment of high-calcium diet with bisphosphonate in the tibial diaphyses of growing-phase rats. The main component of steroids, glucocorticoid, inhibits bone matrix formation in childhood, which then results in a decrease in bone density ${ }^{19)}$. On the other hand, etidronate used as a bisphosphonate reverses the decrease of bone density by inhibiting bone resorption $^{20,21)}$. Furthermore, since a high calcium intake raises calcium absorption in the intestine, we considered the combined treatment of high calcium and bisphosphonate for the treatment of secondary osteoporosis in childhood.

In this study, biomechanical analyses of trabecular and cortical bones were conducted using two-dimensional microdensitometry and threedimensional pQCT method. In addition, the following evaluations were carried out to examine the effect of the combined treatment of high calcium and bisphosphonate in steroid-induced osteoporotic rat tibiae: noninvasive bone strength measurements and quantitative measurements of four elements $(\mathrm{Ca}, \mathrm{P}$, $\mathrm{Mg}, \mathrm{Zn})$ in bone matrix. Two-dimensional microdensitometry demonstrated significantly higher bone density in group $6 \mathrm{St} \cdot 3 \mathrm{HcBp}$ than in group $6 \mathrm{St} \cdot 3 \mathrm{Hc}$ $(p<0.01)$. This could have resulted from an increase in calcium absorption in the intestine due to UNICAL $^{\circledR}$ treatment ${ }^{22)}$ coupled with a suppression of bone density decrease due to bisphosphonate administration.

Three-dimensional pQCT analysis demonstrated that CtBMD and Peri were significantly lower in group 6St than in group 6Co $(\mathrm{p}<0.01$ and $\mathrm{p}<0.05$, respectively). This result suggested that steroids had a prominent effect on the internal structures of bone. CtBMD, CtBMC, CtCSA, and Peri were also significantly lower in group $6 \mathrm{St} \cdot 3 \mathrm{Hc}$ than in group $9 \mathrm{Co}$ $(\mathrm{p}<0.05, \mathrm{p}<0.05, \mathrm{p}<0.01$, and $\mathrm{p}<0.01$, respectively). This result suggested that a shift occurred rapidly in steroid-induced bone from a high-turnover metabolic condition of childhood to a lower metabolic turnover. In previous studies, calcium, vitamin $\mathrm{D}$, or bisphosphonates were reportedly used as single agents in the treatment of steroid-induced osteoporosis ${ }^{11,23,24}$. Our study showed that single, early high-calcium treatment was not enough to recover the metabolic condition of bone as compared to the control group. On the other hand, all the bone measurement parameters including CtBMD, CtBMC, CtCSA, Peri, and Endo were significantly higher in high calcium+bisphosphonate treatment group $(6 \mathrm{St} \cdot 3 \mathrm{HcBp})$ than in high-calcium-only treatment group $(6 \mathrm{St} \cdot 3 \mathrm{Hc})(\mathrm{p}<0.05, \mathrm{p}<0.05, \mathrm{p}<0.01, \mathrm{p}<0.01$, and $\mathrm{p}<0.01$, respectively). These results clearly showed that a combined administration of high calcium and bisphosphonate was an effective therapeutic method in improving the fragile state of bone health, especially during the growing phase of childhood with high bone turnover.

On SSI index, the bone strength indices with reference to the x-axis (xSSI) and polar-axis (pSSI) were significantly lower in group 6St than in group $6 \mathrm{Co}(\mathrm{p}<0.05$ and $\mathrm{p}<0.05$, respectively). This result meant that the bending and torsional strength decreased, thereby suggesting a remodeling situation of bone formation. On the other hand, xSSI of group $6 \mathrm{St} \cdot 3 \mathrm{HcBp}$ became significantly higher than that of group $6 \mathrm{St} \cdot 3 \mathrm{Hc}(\mathrm{p}<0.01)$. This result indicated that the combined administration of high calcium and bisphosphonate could improve the bending strength of bone.

On the four elements in bone matrix, group 
$6 \mathrm{St} \cdot 3 \mathrm{Hc}$ failed to reach the level present in group 9Co. This result suggested that a single treatment with high calcium supply was not sufficient to recover the bone. Group $6 \mathrm{St} \cdot 3 \mathrm{HcBp}$ showed significantly larger amounts of $\mathrm{Ca}, \mathrm{P}, \mathrm{Mg}$, and $\mathrm{Zn}$ than in group $6 \mathrm{St} \cdot 3 \mathrm{Hc}$, whereby the mineral content levels reached or exceeded those of 9Co. This result indicated that bisphosphonate could have contributed significantly to the increase in mineral content.

$\mathrm{Mg}$ and $\mathrm{Zn}$ play a vital role in bone metabolism. $\mathrm{Mg}$ is assumed to be stored in bone as well as Ca, and that it displaces $\mathrm{Ca}$ in apatite crystals. It is included in the substrate follicle, and works as a catalyst when alkaline phosphatase plays the role of supplying $\mathrm{P}$ necessary for calcification in bone formation $^{25)}$. Zn also plays an important role in bone metabolism, such as accelerating bone formation by activating aminoacyl-tRNA synthetase and stimulating bone protein synthesis ${ }^{26)}$. It also works as an inhibitor to bone resorption by exhibiting an inhibitory effect on osteoclast-like cell formation in mouse marrow culture ${ }^{27)}$. On the effects of bisphosphonate on $\mathrm{Mg}$ and $\mathrm{Zn}$, no other data were available apart from the present study. On this note, further research might be required.

The present study revealed that all the elements, $\mathrm{Ca}, \mathrm{P}, \mathrm{Mg}$ and $\mathrm{Zn}$, significantly increased through a combined treatment of high calcium and bisphosphonate for osteoporosis. Therefore, results of this study indicated that such a combined treatment might be effective for the early treatment of steroid-induced osteoporosis.

\section{ACKNOWLEDGEMENTS}

The authors would like to express their gratitude to Dr. Kiichi Nonaka, Research Laboratory of Elk Corporation, and Dr. Toru Takagi, PhD., for their helpful advice.

\section{REFERENCES}

1) Trapani S, Civinini R, Ermini M, Paci E, Falcini F. Osteoporosis in juvenile systemic lupus erythematosus: a longitudinal study on the effect of steroids on bone mineral density. Rheumatol Int 1998; 18(2): 45-49.

2) Alekseev EI, Shakhbazian IE, Ulybina OV, Khudoleeva EIu. Effectiveness and side-effects of long-term treatment with glucocorticoids in patients with juvenile rheumatoid arthritis. Klin Med (Mosk) 2001; 79(3): 33-38.

3) Fakhouri F, Bocquet N, Taupin P, Presne C, Gagnadoux MF, Landais P, Lesavre P, Chauveau D, Knebelmann B, Broyer M, Grunfeld JP, Niaudet P. Steroid-sensitive nephrotic syndrome: from childhood to adulthood. Am J Kidney Dis 2003; 41(3): 550-557.

4) Hodson EM, Knight JF, Willis NS, Craig JC.
Corticosteroid therapy for nephrotic syndrome in children. Cochrane Datebase Syst Rev 2004; (2): CD001533.

5) Wolthers OD, Pedersen S. Growth of asthmatic children during treatment with budesonide: a double blind trial. BMJ 1991; 303(6795): 163-165.

6) Haugeberg G, Griffiths B, Sokoll KB, Emery P. Bone loss in patients treated with pulses of methylprednisolone is not negligible: a short term prospective observational study. Ann Rheum Dis 2004; 63(8): 940-944.

7) Morinushi T, Kinjyo S, Yoshihara T, Yamasaki Y. Correspondence for third molar in disabled patients. J Oral Maxillofac Surg 2005; 15(2): 91-97.

8) Tatehara S, Kitaoka E, Momota Y, Takechi M, Nakanishi H, Nagayama M. Long-term observation of lymphangioma of the tongue. J Oral Maxillofac Surg 2005; 15(2): 115-117.

9) Avioli LV. Glucocorticoid effects on statural growth. Br J Rheumatol 1993; 32 Suppl 2: 2730.

10) Cauza E, Etemad M, Winkler F, Hanusch-Enserer U, Partsch G, Noske H, Dunky A. Pamidronate increases bone mineral density in women with postmenopausal or steroid-induced osteoporosis. J Clin Pharm Ther 2004; 29(5): 431-436.

11) Shaker JL, Lukert BP. Osteoporosis associated with excess glucocorticoids. Endocrinol Metab Clin North Am 2005; 34(2): 341-356.

12) Rodevand E, Mikkelsen K, Nordvag BY, Haga HJ, Forre O, Johnsen V, Kvien TK. Medical prophylaxis and treatment of steroid induced osteoporosis. Tidsskr Nor Laegetoren 2005; 125(12): 1643-1645.

13) Grazio S, Korsic M, Anic B, Vitezic-Misjak M, Grubisic F. Glucocorticoid-induced osteoporosis: review and proposition for prevention and treatment guidelines. Lijec Vjesn 2005; 127(1-2): 36-43.

14) Summey BT, Yosipovitch G. Glucocorticoid-induced bone loss in dermatologic patients: an update. Arch Dermatol 2006; 295(11): 1300-1303.

15) Gunjima M, Tofani I, Kojima Y, Maki K, Kimura M. Mechanical evaluation of effect of grape seed proanthocyanidins extract on debilitated mandibles in rats. Dent Mater J 2004; 23(2): 67-74.

16) Yahara N, Tofani I, Maki K, Kojima K, Kojima Y, Kimura M. Mechanical assessment of effects of grape seed proanthocyanidins extract on tibial bone diaphysis in rats. $\mathrm{J}$ Musculoskelet Neuronal Interact 2005; 5(2): 162-169.

17) Kamitani Y, Maki K, Tofani I, Nishikawa Y, Tsukamoto K, Kimura M. Effects of grape seed proanthocyanidins extract on mandibles in developing rats. Oral Dis 2004; 10(1): 27-31.

18) Ishikawa M, Maki K, Tofani I, Kimura K, Kimura M. Grape seed proanthocyanidins extract promotes bone formation in rat's mandibular condyle. Eur J Oral Sci 2005; 113: 47-52.

19) Popp AW, Isenegger J, Buergi EM, Buergi U, Lippuner K. Glucocorticosteroid-induced spinal osteoporosis: scientific update on pathophysiology and treatment. Eur Spine J 2006; 11: 1-15

20) Adachi JD, Roux C, Pitt PI, Cooper C, Moniz C, Dequeker J, Ioannidis G, Cawley MI, Jenkins EA, Walker-Bone KE, Pack S, Stephenson GF, Laan RF, Brown J, Geusens P. A pooled data analysis on the 
use of intermittent cyclical etidronate therapy for the prevention and treatment of corticosteroid induced bone loss. J Rheumatol 2000; 27(10): 24242431.

21) Campbell IA, Douglas JG, Francis RM, Prescott RJ, Reid DM; Research Committee of the British Thoracic Society. Five year study of etidronate and/ or calcium as prevention and treatment for osteoporosis and fractures in patients with asthma receiving long term oral and/or inhaled glucocorticoids. Thorax 2004 Sep; 59(9): 761-768.

22) Qin M, Zhang Z, Maki K, Naito M, Morimoto A, Kimura M. The effect of calcium supplement given with a mixture of calcium carbonate and calcium citrate on the mandibular alveolar bone of pubertal rats. J Bone Metab 1998; 16: 88-95.

23) Rodevand E, Mikkelsen K, Nordvag BY, Haga HJ, Forre O, Johnsen V, Kvien TK. Medical prophylaxis and treatment of steroid induced osteoporosis. Tidsskr Nor Laegeforen 2005; 125(12): 1643-1645.

24) Blalock SJ, Norton LL, Patel RA, Dooley MA. Patient knowledge, beliefs, and behavior concerning the prevention and treatment of glucocorticoidinduced osteoporosis. Arthritis Rheum 2005; 53(5): 732-739.

25) Okazaki M, Takahashi J, Kimura H. Unstable behavior of magnesium-containing hydroxyapatites. Caries Res 1986; 20: 324-331.

26) Yamaguchi M, Oishi H, Suketa Y. Zinc stimulation of bone protein synthesis in tissue culture. Activation of aminoacyl-tRNA synthetase. Biochem Pharmacol 1988; 37: 4075-4080.

27) Kishi S, Yamaguchi M. Inhibitory effect of zinc compounds on osteoclast-like cell formation in mouse marrow cultures. Biochem Pharmacol 1994; 48: 1225-1230. 